\title{
Pemahaman Konsep Pereaksi Pembatas Hasil Pembelajaran Kimia Menggunakan LKS-Induktif Pada Siswa Kelas X
}

\author{
Ike Valentie \\ SMA Negeri 1 Palangka Raya, Provinsi Kalimantan Tengah, Indonesia \\ Email: ike.valentie@yahoo.co.id
}

\begin{abstract}
Abstrak: Materi atau konsep pereaksi pembatas merupakan bagian dari stoikiometri. Ini berarti bahwa untuk mempelajari materi pereaksi pembatas siswa harus sudah memahami dan menguasai konsep prasyarat yakni rumus kimia, persamaan kimia dan konsep mol. Penelitian ini bertujuan untuk: mendeskripsikan pemahaman konsep siswa SMA Negeri 1 Palangka Raya mengenai pereaksi pembatas sebelum dan sesudah pembelajaran menggunakan LKS-induktif. Penelitian ini melibatkan 68 siswa kelas X MIPA-1 dan X MIPA-4 SMA Negeri 1 Palangka Raya. Instrumen yang digunakan adalah lembar soal pretes dan postes, LKS-Induktif. Data dikumpulkan melalui tiga tahap yaitu pretes, pelaksanaan pembelajaran dengan penggunaan LKS-Induktif, dan postes. Data yang diperoleh dianalisis secara deskriptif. Hasil penelitian menunjukkan bahwa pemahaman konsep pereaksi pembatas siswa saat pretes adalah 3,36\% dan pemahaman konsep siswa saat postes adalah 69,32\%. Perubahan pemahaman konsep siswa meningkat sebesar 65,96\% dapat diklasifikasikan ke dalam kategori baik. Secara rinci pemahaman konsep pereaksi pembatas siswa sebagai berikut: a) pemahaman konsep mendefinisikan pengertian pereaksi pembatas sebesar 52,58\%; (b) pemahaman konsep menentukan pereaksi pembatas sebesar 69,32\%.
\end{abstract}

\section{Kata kunci: LKS-Induktif, Pemahaman Konsep, Pereaksi Pembatas}

\section{Pendahuluan}

Belajar adalah proses berpikir. Belajar berpikir merupakan proses siswa mencari dan memperoleh pengetahuannya sendiri melalui interaksi antara individu dengan lingkungan (Sanjaya, 2010). Usaha-usaha siswa memperoleh pengetahuan akan menumbuhkan kemampuan berpikir (Anderson, 2010). Belajar berpikir menyebabkan seseorang belajar lebih dari mengingat dan memahami untuk menemukan solusi baru dari persoalan yang dihadapinya. Pemberian pengalaman belajar secara langsung lebih menekankan pada penggunaan dan pengembangan keterampilan dan sikap ilmiah. Salah satu masalah yang dihadapi dunia pendidikan adalah dalam proses pembelajaran, siswa kurang didorong mengembangkan kemampuan berpikir.

Pelajaran kimia merupakan salah satu pelajaran yang menggunakan keterampilan dalam memecahkan masalah dengan menggunakan fakta, konsep, prinsip, hukum dan teori. Pembelajaran yang dimulai dari masalah-masalah aktual, otentik menuntut keaktifan siswa memperoleh suatu informasi dan pemecahan masalah sehingga mampu membuktikan kebenaran suatu konsep. Pembelajaran yang dimulai dari masalah membuat siswa belajar konsep sekaligus memecahkan masalah. Keberhasilan pembelajaran dapat diukur dari kemampuan siswa dari tingkat pemahaman, penguasaan materi, kemampuan penalaran serta hasil belajar siswa. Semakin tinggi pemahaman dan pengusaan materi serta hasil belajar maka semakin tinggi pula tingkat keberhasilan pembelajaran. 
Pemahaman terhadap konsep dan prinsip dasar tersebut merupakan modal dasar bagi penguasaan selanjutnya seperti yang diungkapkan Sudyana (2006). Penguasaan konsep-konsep kimia yang saling keterkaitan memerlukan metode pembelajaran yang berbeda dengan materi yang lainnya sesuai dengan materi yang dipelajari dan tujuan yang hendak dicapai. Hal ini menjadikan pelajaran kimia sering terkesan lebih sulit dipelajari. Chang (2003) mengungkapkan salah satu alasan kesan sulit yaitu beberapa konsep kimia bersifat abstrak. Chang menyarankan untuk menguasai konsep kimia yang bersifat abstrak itu dengan kemampuan berpikir kritis. Permendiknas 81 A tahun 2013 mengemukakan bahwa untuk membudayakan berpikir secara kritis pada siswa. Keterampilan berpikir kritis dapat dibangun ketika siswa melaksanakan penyelidikan untuk menemukan suatu konsep. Saat siswa melakukan penyelidikan maka siswa berpikir untuk mencari apa yang harus diketahui dan apa yang belum diketahui, berpikir untuk memecahkan masalahnya, mengevaluasi yang telah dilakukannya.

Selama ini ada beberapa pemahaman siswa terhadap senyawa pereaksi pembatas tergolong kurang, yaitu siswa telah mampu menghitung jumlah mol dari zat-zat pereaksi, namun belum mampu menentukan zat yang menjadi pereaksi pembatas dan zat pereaksi yang tersisa dalam reaksi tersebut. Siswa dalam hal ini lebih banyak belajar memecahkan soal matematis tanpa mengerti dan memahami makna yang sesungguhnya.

Materi pereaksi pembatas merupakan bagian dari Stoikiometri, dan dipelajari terakhir dari materi stoikiometri. Artinya untuk mempelajari materi pereaksi pembatas siswa sudah memahami dan menguasai hukum-hukum dasar yang meliputi hukum kekekalan massa, hukum perbandingan tetap, hukum perbandingan berganda, hukum perbandingan volume, hipotesis Avogadro, dan konsep mol. Hukum kekekalan massa menyatakan massa sebelum reaksi sama dengan massa sesudah reaksi. Banyaknya zat pereaksi ataupun produk diperoleh jika persamaan reaksi sudah setara.

Zat-zat pereaksi yang dicampurkan seringkali tidak dalam jumlah yang ekivalen, artinya perbandingan mol tidak sesuai dengan perbandingan koefisien reaksinya. Apabila terjadi hal seperti itu, maka salah satu pereaksi akan habis lebih dahulu, sementara pereaksi lainnya bersisa. Jumlah hasil reaksi akan bergantung pada jumlah pereaksi yang habis lebih dahulu, artinya zat pereaksi yang habis lebih dahulu akan membatasi jumlah hasil reaksi. Zat pereaksi yang habis bereaksi akan membatasi hasil reaksi disebut pereaksi pembatas, seperti yang diungkapkan Sudarmo (2013).

Pada tahun 2000 Anggariyani melakukan penelitian topik Stoikiometri di SMA Kristen, Palangka Raya. Hasil penelitiannya menunjukkan rerata skor total sebesar 2,85 dengan standar ketuntasan minimal mata pelajaran Kimia adalah 6 . Skor 2,85 menyatakan hampir seluruh siswa mengalami kesulitan menyelesaikan soal yang berhubungan dengan konsep stoikiometri. Pereaksi pembatas merupakan bagian dari konsep stoikiometri. Penelitian yang dilakukan oleh Sidauruk (2005) pada siswa SMA tentang Miskonsepsi Stoikiometri bahwa siswa mengalami miskonsepsi terhadap konsep pereaksi pembatas. Siswa memahami pereaksi pembatas sebagai: 1). Zat yang memiliki koefisien reaksi/mol/massa terkecil; 2). Zat yang memiliki koefisien reaksi/mol/massa terbesar. Miskonsepsi 
seperti ini dialami siswa karena tidak memahami pengertian pereaksi pembatas yang sesungguhnya.

Kurangnya kemampuan siswa dalam bernalar (kemampuan berpikir kritis) dikarenakan pola pembelajaran lebih menekankan pada menghafal konsepkonsep yang dipelajari. Holbrook menyatakan bahwa kebiasaan belajar dengan cara menghafal akan menyebabkan kemampuan berpikir sebatas lower order thinking (Arantika, dkk, 2014). Kemampuan penalaran belajar kimia yaitu: 1). Menarik kesimpulan logik, memberikan penjelasan dengan menggunakan model, fakta, sifat, konsep dan hukum, 2). Memperkirakan jawaban dan proses solusi dan menggunakan data dan hubungan untuk menganalisis data, menarik analogi dan generalisasi.

Pengetahuan tentang pereaksi pembatas merupakan pengetahuan konseptual dan prosedural. Menurut Hilbert (Rivai, 2013) pengetahuan konseptual dapat diartikan sebagai suatu jaringan pengetahuan yang menghubungkan penggalan-penggalan informasi yang telah tersimpan di dalam memori atau antara suatu penggalan pengetahuan yang telah ada dengan yang baru dipelajari. Pengetahuan konseptual mencakup klasifikasi, bentuk, konsep, bentuk, struktur. Pemahaman konsep pereaksi pembatas menghubungkan dengan konsep mol, persamaan reaksi, rumus kimia. Pengetahuan prosedural adalah pengetahuan yang dibentuk dari algoritma-algoritma atau aturan-aturan untuk menyelesaikan soalsoal hitungan kimia.

Diperlukan strategi pembelajaran yang tepat di mana guru tidak menyajikan materi yang bersifat abstrak tetapi membimbing siswa berpikir dalam melakukan penalaran untuk memperoleh pengetahuan baru. Agar siswa dapat melakukan penalaran secara efektif maka perlu media. Salah satunya dengan menggunakan Lembar Kerja Siswa (LKS). Penggunaan penalaran induktif dalam LKS yaitu untuk memahami informasi yang bersifat khusus, berupa pernyataan khusus mengenai pereaksi pembatas agar selanjutnya menarik kesimpulan yang bersifat umum berdasarkan data yang diamati. Pembelajaran menggunakan LKSinduktif untuk mengaktifkan siswa secara optimal dan memotivasi siswa untuk berpikir kritis, sehingga berpengaruh terhadap kemampuan siswa dalam memahami konsep pereaksi pembatas.

Berdasarkan uraian di atas, maka perlu dilakukan penelitian untuk mengetahui pengaruh penggunaan LKS-induktif dalam menjaring pemahaman konsep siswa mengenai konsep pereaksi pembatas. Penelitian yang dilakukan untuk menjawab: Bagaimana pemahaman konsep pereaksi pembatas hasil pembelajaran kimia menggunakan LKS-induktif pada siswa kelas X SMA Negeri 1 Palangka Raya tahun pelajaran 2017/2018? Tujuan penelitian ini adalah mendeskripsikan pemahaman konsep siswa SMA Negeri 1 Palangka Raya mengenai pereaksi pembatas sebelum dan sesudah pembelajaran menggunakan LKS-induktif.

Hasil penelitian secara teoritis diharapkan dapat memberikan sumbangan pemikiran dalam pengembangan sistem pembelajaran, dan memperkaya kajian untuk sumber bacaan tentang pereaksi pembatas. Penelitian ini diharapkan dapat memberi manfaat :sebagai sumbangan pemikiran bagi guru dalam merencanakan pembelajaran dengan menggunakan LKS-induktif, dan menjadi sarana informasi untuk melakukan penelitian lebih lanjut. 


\section{Metodologi Penelitian}

Penelitian ini merupakan penelitian deskriftif, menggambarkan secara jelas mengenai perubahan pemahaman konsep siswa tentang pereaksi pembatas dalam pembelajaran dengan menerapkan model LKS-Induktif. Penelitian dilaksanakan di SMAN 1 Palangka Raya pada akhir semester genap tahun pelajaran 2017/2018. Penelitian dilakukan pada siswa kelas $\mathrm{X}$ yang belum mempelajari materi pereaksi pembatas. Penelitian dilaksanakan di SMA Negeri 1 Palangka Raya. Terdapat 7 kelas X MIPA di sekolah ini. Dari populasi dipilih kelas sebagai sampel penelitian dengan menggunakan teknik acak kelompok (random sampling). Berdasarkan teknik tersebut terpilih kelas sebagai subjek penelitian ini adalah kelas X MIPA -1 dan X MIPA-4.

Data yang diperlukan untuk menjawab masalah penelitian ini adalah untuk memperoleh data tersebut perlu disiapkan instrumen. Dari penyusunan instrumen, data yang diperoleh untuk penelitian ini meliputi data pemahaman konsep, LKS dan lembar pengamatan aktivitas belajar siswa dan wawancara.

Tabel 1.Teknik Pengembangan Instrumen

\begin{tabular}{|c|c|c|}
\hline $\begin{array}{l}\text { Data yang } \\
\text { Diperoleh }\end{array}$ & Teknik Pengumpulan Data & Instrumen \\
\hline $\begin{array}{l}\text { Kemampuan belajar } \\
\text { siswa }\end{array}$ & $\begin{array}{ll}\text { - } & \text { Memberikan LKS dan } \\
\text { mengumpulkan kembali } \\
\text { setelah dikerjakan siswa } \\
\text { - } & \text { Wawancara }\end{array}$ & LKS \\
\hline $\begin{array}{l}\text { Pemahaman } \\
\text { Konsep Siswa }\end{array}$ & 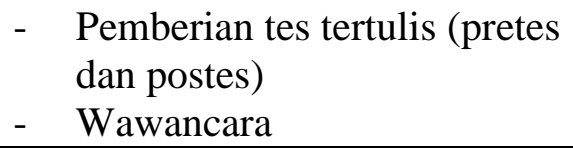 & $\begin{array}{l}\text { Soal } \\
\text { Pemahaman } \\
\text { Konsep Siswa }\end{array}$ \\
\hline
\end{tabular}

Soal tes pemahaman konsep terdiri dari dua macam yaitu soal pretes dan soal postes dalam bentuk uraian objektif. Soal pretes dan postes yang digunakan sebelumnya dibuat dalam kisi-kisi instrumen tes pemahaman konsep pereaksi pembatas. Soal-soal tes diseleksi untuk memperoleh banyaknya butir soal yang akan digunakan dalam tes, menyesuaikan dengan alokasi waktu pembelajaran kimia kelas $\mathrm{X}$ yaitu 3 jam pelajaran yang setara dengan 135 menit.

Diperoleh soal pretes dan postes pereaksi pembatas yang digunakan sebagai instrumen ada 7 butir soal dalam bentuk tes uraian objektif. Soal pada pretes dan postes merupakan soal yang berbeda tetapi memiliki tujuan pembelajaran yang sama dan bobot isi yang sama. Penskoran untuk tiap butir soal memiliki kriteria tertentu pada tiap langkah penyelesaian soal. Kriteria tersebut sesuai dengan pemahaman konsep yang diperoleh siswa. Skor pretes dan postes untuk butir soal 1 sampai dengan 7 memiliki maksimum yang beragam. Kisi-kisi tes pereaksi pembatas dapat dilihat pada Tabel 2.

Tabel 2. Kisi-Kisi Penyusunan Soal Tes Pemahaman Konsep (Pretes dan Postes)

\begin{tabular}{|c|c|c|c|c|c|}
\hline \multirow[t]{2}{*}{ Indikator } & \multirow[t]{2}{*}{$\begin{array}{c}\text { Tujuan } \\
\text { Pembelajaran }\end{array}$} & \multirow[t]{2}{*}{ Substansi Soal } & \multicolumn{2}{|c|}{$\begin{array}{c}\text { Nomor Butir } \\
\text { Soal }\end{array}$} & \multirow{2}{*}{$\begin{array}{c}\text { Jumlah } \\
\text { Butir } \\
\text { Soal }\end{array}$} \\
\hline & & & Pretes & Postes & \\
\hline $\begin{array}{l}\text { Mendefinisikan } \\
\text { pengertian }\end{array}$ & $\begin{array}{l}\text { Siswa dapat } \\
\text { mendefinisikan }\end{array}$ & $\begin{array}{l}\text { Diberikan } \\
\text { ilustrasi berupa }\end{array}$ & 1 & 1 & 1 \\
\hline
\end{tabular}




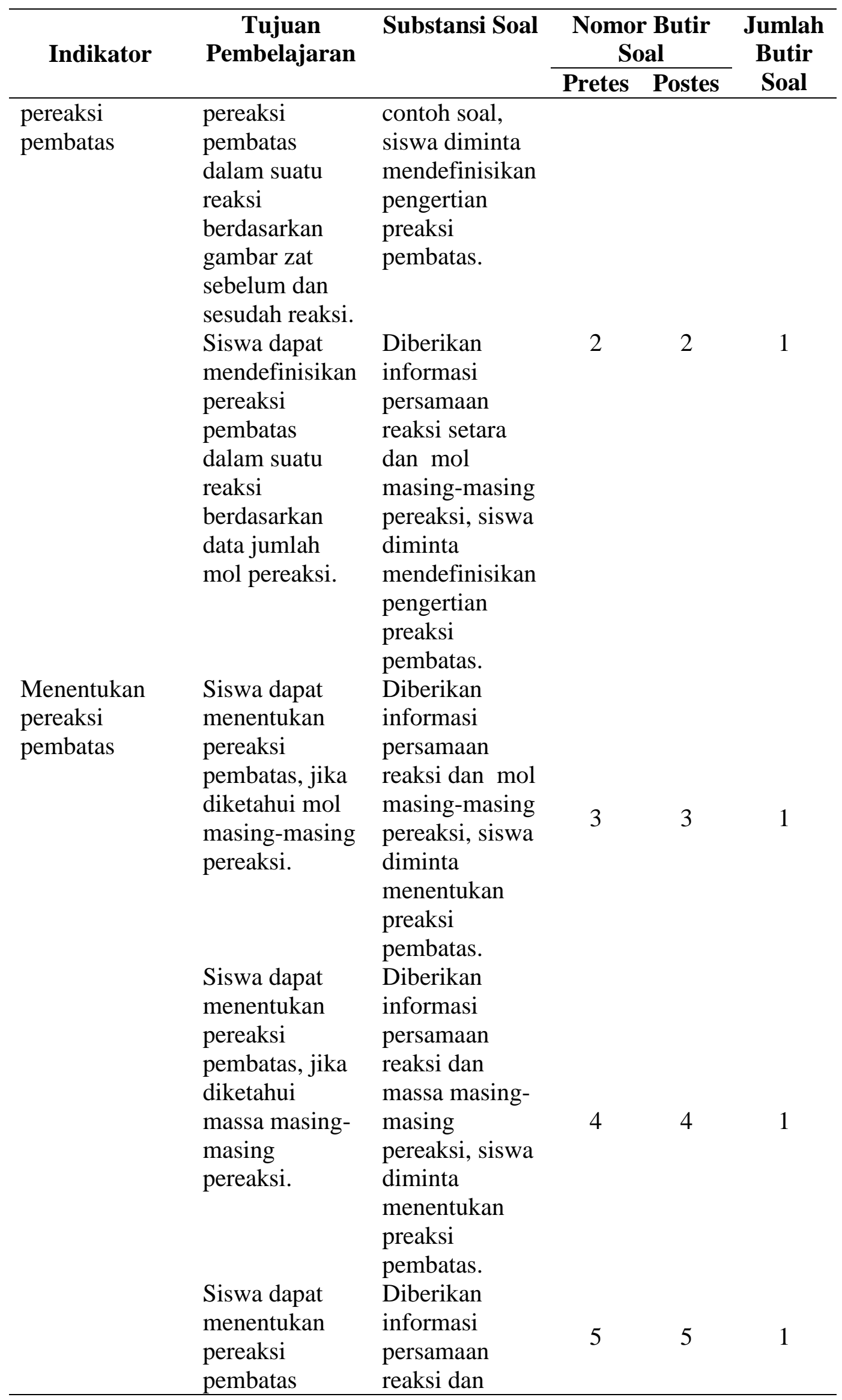




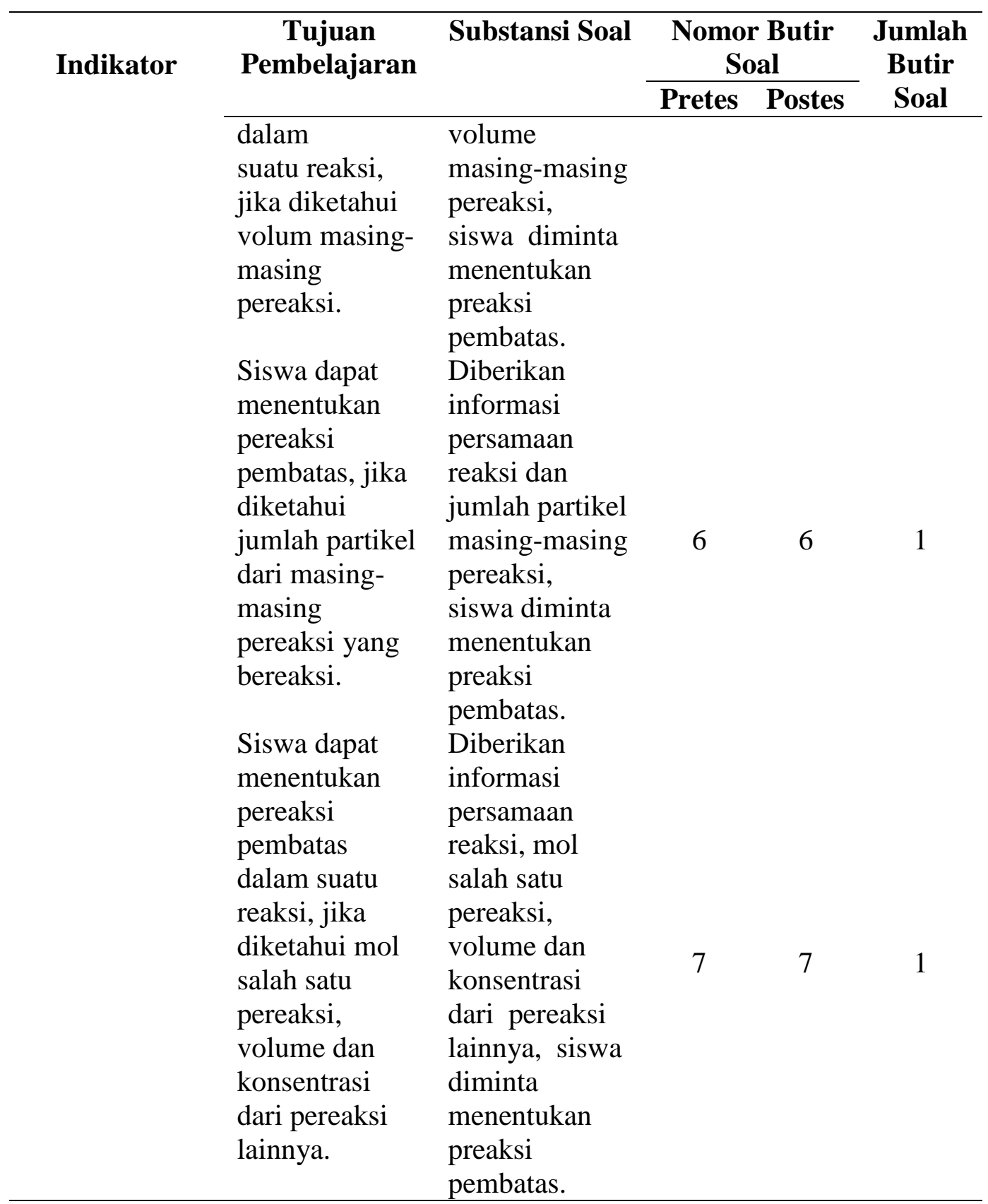

Sebelum penelitian ini dilaksanakan, soal terlebih dahulu divalidasi. Validitas atau kesahihan merujuk pada derajat bukti dan teori mendukung penafsiran skor tes sebagai tujuan penggunaan tes, menurut Standard (Mardapi, 2012). Validasi diperlukan untuk mengetahui informasi tentang kualitas tes uraian objektif, dan LKS pengelolaan pembelajaran. Butir soal dapat disimpulkan valid atau tidak valid secara konten berdasarkan hasil statistik yang menggunakan formula koefisien validitas isi Aiken (V) sebagai berikut:

$$
\mathrm{V}=\frac{\sum \mathrm{s}}{n(\mathrm{c}-1)}
$$

Diperoleh koefisien dengan formula koefisien V Aiken's adalah 1. Perolehan ini dibandingkan dengan Tabel Right Tail Probability for Selected 
Values of The Validity Coefficient (V) dengan harga taraf kepercayaan $(\alpha) 0,05$ dan kategori rating $(c)=3$ menunjukkan harga tabel $=1,00$. Harga $V$ hitung $\geq V$ tabel, maka dapat disimpulkan tes valid secara konten.

Sebelum soal digunakan dalam pretes juga postes, dilakukan uji coba soal untuk memperoleh data tentang tingkat kebaikan dari butir soal yang akan digunakan dalam instrumen penelitian. Perolehan data dalam uji coba tersebut meliputi reliabilitas butir soal, tingkat kesukaran, dan daya pembeda yang selanjutnya dianalisis. Hasil analisis butir soal sebagai dasar untuk butir soal tersebut diterima, direvisi ataukah direvisi butir soal itu sebagai instrumen penelitian. Setelah penelitian dilaksanakan, jawaban soal pretes maupun postes dinilai dengan kriteria jawaban yang tertuang dalam rubrik penilaian. Rubrik penilaian tes pemahaman konsep pereaksi pembatas ditunjukkan pada Tabel 3.

Tabel 3. Contoh Rubrik Penilaian Tes Pemahaman Konsep Pereaksi Pembatas

\begin{tabular}{|c|c|c|}
\hline $\begin{array}{l}\text { Nomor } \\
\text { Soal }\end{array}$ & Kriteria Jawaban & Skor \\
\hline \multirow{3}{*}{ 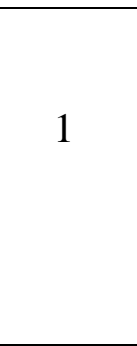 } & $\begin{array}{l}\text { Siswa tidak dapat mendefinisikan pereaksi pembatas } \\
\text { berdasarkan gambar }\end{array}$ & 0 \\
\hline & $\begin{array}{l}\text { Siswa dapat mendefinisikan pereaksi pembatas berdasarkan } \\
\text { gambar sebagai zat yang habis bereaksi }\end{array}$ & 1 \\
\hline & $\begin{array}{l}\text { Siswa dapat mendefinisikan pereaksi pembatas berdasarkan } \\
\text { gambar sebagai zat yang habis bereaksi, membatasi hasil } \\
\text { reaksi menyebabkan pereaksi lain tersisa }\end{array}$ & 2 \\
\hline
\end{tabular}

Instrumen lain yang digunakan saat pelaksanaan pembelajaran berlangsung adalah LKS. Instrumen tersebut disusun berdasarkan silabus mata pelajaran kimia kelas $\mathrm{X}$ dan dikembangkan sesuai dengan indikator bertujuan untuk mengarahkan siswa mencari dan menemukan konsep pereaksi pembatas.

Siswa mengingat kembali konsep yang telah dipelajari sebagai konsep prasyarat. Konsep-konsep tersebut yaitu persamaan reaksi dan perbandingan tetap. Penguasaan konsep persamaan reaksi meliputi materi pereaksi dan hasil reaksi, serta mampu menyetarakan reaksi. Penyetaraaan reaksi berkaitan dengan hukum Lavoiser.

Langkah berikutnya siswa menerapkan perbandingan mol/atom dan perbandingan koefisien ke dalam suatu persamaan reaksi berdasarkan gambar (simbolik). Perbandingan mol atau atom suatu pereaksi sesuai dengan perbandingan koefisien akan didapatkan pereaksi yang habis bereaksi.

Soal hitungan kimia pereaksi pembatas diselesaikan dengan algoritma, menunjukkan pereaksi yang habis bereaksi (pereaksi pembatas) dan pereaksi yang tersisa sehingga diperoleh konsep menentukan zat yang bertindak sebagai pereaksi pembatas.

Lembar pengamatan pengelolaan aktivitas belajar siswa digunakan untuk mengetahui keterlaksanaan proses pembelajaran yang dilakukan peneliti agar sesuai dengan tujuan pembelajaran yang ingin dicapai dalam pembelajaran menggunakan LKS-Induktif.

Wawancara dilakukan terkait dengan pemahaman siswa yang masih belum tuntas berdasarkan hasil tes siswa. Selanjutnya hasil wawancara ditampilkan 
dalam bentuk transkrip dan dianalisis. Analisis data wawancara dimaksudkan untuk mengetahui sebatas mana kemampuan siswa memahami konsep pereaksi pembatas, sehingga guru dapat melakukan interpretasi terhadap kemampuan siswa.

Lembar pengamatan pelaksanaan pembelajaran digunakan untuk mengetahui terlaksana atau tidaknya langkah-langkah pembelajaran dengan menggunakan LKS-Induktif yang dikelola oleh guru di dalam kelas.

Ujicoba instrumen dilakukan pada pembelajaran di kelas XI MIPA-5 yang telah mempelajari pereaksi pembatas pada tanggal 10 April 2018. Tujuan dilakukan ujicoba instrumen adalah guna memperoleh data tentang tingkat kebaikan soal. Berdasarkan data skor siswa tiap butir soal yang diperoleh dari uji coba dapat diketahui reliabilitas butir soal dan dilakukan analisis butir soal. Hasil analisis butir soal ini akan memberikan keterangan diterima atau tidak diterima butir soal tersebut sesuai dengan kriteria tingkat kesukaran dan daya beda butir soal. Tingkat kesukaran (proporsi) butir soal uraian objektif dapat dihitung dengan rumus

$$
P=\frac{\text { mean butir soal }}{\text { skor maksimal butir soal }}
$$

Besarnya indeks tingkat kesukaran antara 0,0 sampai 1,0. Menurut Suharsimi (2009) butir soal yang baik ditunjukkan dengan indeks tingkat kesulitan 0,3-0,7. Tabel 4 menunjukkan kategori kesulitan soal berdasarkan indeks tingkat kesulitan.

Tabel 4. Kategori Tingkat Kesulitan

\begin{tabular}{ll}
\hline Indeks Tingkat Kesulitan $(\mathbf{P})$ & Kategori \\
\hline $0,00>0,29$ & Sukar \\
$0,30>0,70$ & Sedang \\
$0,71>1,00$ & Mudah \\
\hline
\end{tabular}

Parameter kedua dalam analisis butir soal adalah daya pembeda, yaitu untuk membedakan antara siswa yang berhasil dengan siswa yang tidak berhasil menguasai kemampuan. Perhitungan daya beda (DB) tiap butir soal dengan rumus sebagai berikut:

$$
D B=\left(\frac{\text { mean butir soal kelas atas }}{\text { skor maksimal butir soal }}\right)-\left(\frac{\text { mean butir soal kelas bawah }}{\text { skor maksimal butir soal }}\right)
$$

Rentang indeks daya pembeda adalah -1 sampai dengan +1 . Makna harga positif adalah kelompok siswa yang berhasil menguasai kemampuan, menjawab benar.

Data dikumpulkan melalui tahapan-tahapan sebagai berikut: (1) memberikan tes awal (Pretes) yang bertujuan untuk memperoleh data pemahaman dan kemampuan awal siswa dalam menyelesaikan soal pereaksi pembatas yang akan dipelajari. (2) Dilanjutkan pembelajaran menggunakan LKS-Induktif. (3)Tahap terakhir pembelajaran adalah pemberian tes akhir (Postes). Tes akhir 
bertujuan untuk menjaring data kemampuan siswa memahami materi setelah pembelajaran menggunakan LKS-Induktif.

Bagi siswa yang tidak mengalami perubahan hasil pretes dan postes maka dilakukan wawancara terhadap siswa tersebut.

Persentase Pemahaman Konsep untuk setiap siswa:

$$
P=\frac{\sum \text { skor yang diperoleh siswa }}{\sum \text { Skor maksimum }} \times 100 \%
$$

Persentase pemahaman konsep siswa (P) sebelum pembelajaran (pretes) dan sesudah pembelajaran (postes) dibandingkan sehingga dapat diketahui pemahaman konsep siswa dalam pembelajaran mengalami peningkatan atau tidak, dan dapat diklasifikasikan peningkatan pemahamannya.

Tabel 5. Klasifikasi Tingkat Pemahaman

\begin{tabular}{ccc}
\hline Tingkat Pemahaman & $\begin{array}{c}\text { Persentase } \\
\text { Pemahaman }(\%)\end{array}$ & Kriteria \\
\hline I & $0-20$ & Kurang sekali \\
II & $21-40$ & Kurang \\
III & $41-60$ & Cukup \\
IV & $61-80$ & Baik \\
V & $81-100$ & Sangat Baik \\
\hline
\end{tabular}

Data yang diperlukan dalam hasil belajar LKS-Induktif dianalisis secara deskriptif untuk mendeskripsikan hasil belajar siswa tentang pereaksi pembatas menggunakan LKS-Induktif. Persentase Hasil Belajar Pemahaman Konsep menggunakan LKS-Induktif untuk setiap siswa:

$$
P=\frac{\sum \text { skor yang diperoleh siswa }}{\sum \text { Skor maksimum }} \times 100 \%
$$

Acuan yang digunakan untuk hasil belajar memahami konsep pereaksi pembatas dalam pembelajaran menggunakan LKS-Induktif dapat dilihat pada Tabel 5 (sumber Suharsimi, 2003).

\section{Hasil Penelitian Dan Pembahasan}

Penelitian dilaksanakan di kelas X SMA Negeri 1 Palangka Raya pada akhir semester genap tahun pelajaran 2017/2018, dengan pengambilan data penelitian pada tanggal 16 dan 18 Mei 2018 disesuaikan dengan jadwal pelajaran. Subjek penelitian yang terpilih dengan teknik acak kelompok adalah siswa-siswa kelas X MIPA-1 dan X MIPA-4 sebanyak 74 siswa, namun pada pelaksanaannya ada 6 siswa yang tidak hadir, sehingga diperoleh data penelitian dari 68 siswa. Dilakukan dengan tahap pertama pemberian pretes. Tahap kedua adalah guru melakukan pembelajaran menggunakan LKS-Induktif dikerjakan siswa secara mandiri dalam kelompok. Tahap selanjutnya pemberian postes berisikan soal yang berbeda dengan soal pretes, tetapi memiliki bobot nilai yang sama. Pergeseran 
pemahaman konsep siswa dapat dilihat nilai tes yang diperoleh sebelum dan sesudah pembelajaran menggunakan LKS-Induktif. Siswa yang tidak mengalami pergeseran pemahaman dilakukan wawancara pasca pembelajaran dan di luar jam pelajaran dengan menanyakan hal-hal yang diperlukan, untuk mengetahui pemahaman siswa yang lebih mendalam.

Hasil pretes diperoleh skor minimum pretes adalah 0 dan skor tertinggi 6,9. Nilai rata-rata pretes siswa adalah $1,62 \%$ dengan kategori tingkat pemahaman kurang sekali. Hal ini terjadi karena siswa belum pernah mempelajari konsep Pereaksi Pembatas. Setelah pretes dilanjutkan pada kegiatan pembelajaran menggunakan LKS-Induktif, kemudian dilaksanakan pemberian postes setelah pembelajaran berakhir. Skor terrendah untuk postes adalah 10,34 dan skor tertertinggi 100. Nilai rata-rata postest yang diperoleh siswa sebesar $65,82 \%$ dengan kategori tingkat pemahaman baik, menunjukkan adanya peningkatan pemahaman konsep siswa setelah mempelajari konsep Pereaksi Pembatas menggunakan LKS-Induktif.

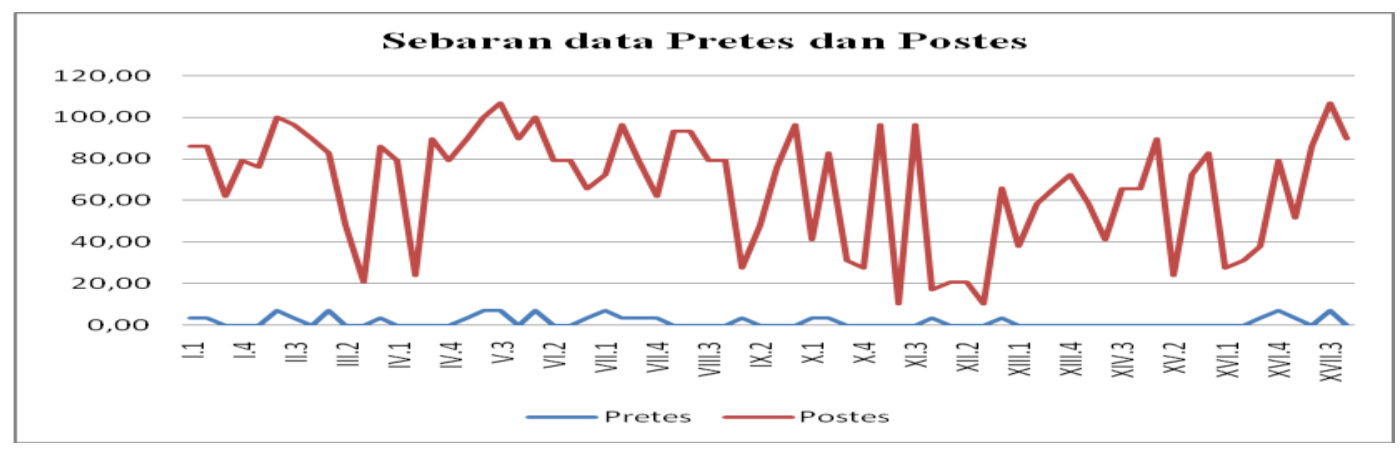

Gambar 1. Sebaran data Pretes dan Postes

Pasca pembelajaran menggunakan LKS-Induktif, semua siswa mengalami peningkatan pemahaman. Hal ini dapat dilihat dari rata-rata nilai siswa saat postes yaitu 64,34 dan 69,32. Jumlah peningkatan persentase siswa yang menjawab benar yaitu 52,58 dan 69,32 masing-masing untuk indikator mendefinisikan pengertian pereaksi pembatas dan indikator menentukan pereaksi pembatas.

Deskripsi data kemampuan belajar siswa memahami konsep Pereaksi Pembatas dalam pembelajaran dengan LKS-Induktif.

Pelaksanaan pembelajaran pada penelitian ini meliputi beberapa tahapan yang dilakukan sesuai dengan tahapan pada pembelajaran, yaitu kegiatan pendahuluan. Selanjutnya, dalam kegiatan inti guru membagi kelompok yang terdiri dari 4 orang dalam satu kelompok, dan LKS-Induktif diberikan kepada setiap kelompok untuk didiskusikan. Hal ini bertujuan mengetahui sejauh mana kemampuan siswa menerapkan konsep yang akan dipelajari dengan saling bekerjasama mengerjakan LKS-Induktif, berdiskusi, tanya jawab antar sesama teman. Akhir kegiatan pembelajaran guru memberikan postes yang bertujuan untuk mengetahui peningkatan pemahaman konsep setelah pembelajaran menggunakan LKS-Induktif pada materi Pereaksi Pembatas.

Rata-rata skor pretes adalah 3,36\%, sedangkan rata-rata skor postes adalah $65,82 \%$. Rata-rata skor postes lebih besar dari rata-rata skor pretes. Hal ini menunjukkan terjadi peningkatan pemahaman konsep siswa setelah siswa diberikan pembelajaran menggunakan LKS-Induktif. Peningkatan pemahaman 
siswa pada setiap indikator setelah pembelajaran menggunakan LKS-Induktif tercantum pada Tabel 6.

Pada Tabel 6, dari nilai rata-rata pretes dan postes menunjukkan adanya peningkatan pemahaman siswa. Indikator 1 mengenai pemahaman konsep mendefinisikan pengertian pereaksi pembatas. Peningkatan pemahaman siswa mendefinisikan pengertian pereaksi berdasarkan gambar (secara makroskopis) adalah $47,80 \%$ dapat dirujuk pada butir soal 1 . Nilai rata-rata pretes dan postes untuk butir soal 2 menunjukkan adanya peningkatan pemahaman mendefinisikan pengertian pereaksi pembatas berdasarkan data jumlah mol atau jumlah atom pereaksi (secara mikroskopis) sebesar 57,36\%. Rata-rata peningkatan pemahaman konsep mendefinisikan pengertian pereaksi pembatas dari dua butir soal tersebut adalah $52,58 \%$.

Tabel 6. Peningkatan Pemahaman Konsep Siswa

\begin{tabular}{lcccc}
\hline \multicolumn{1}{c}{ Indikator } & $\begin{array}{l}\text { Nomor. } \\
\text { Butir } \\
\text { Soal }\end{array}$ & $\begin{array}{l}\text { Pemahaman } \\
\text { siswa pada } \\
\text { pretes (\%) }\end{array}$ & $\begin{array}{l}\text { Pemahaman } \\
\text { siswa pada } \\
\text { postes (\%) }\end{array}$ & $\begin{array}{c}\text { Peningkatan } \\
\text { Pemahaman } \\
(\%)\end{array}$ \\
\hline 1. Mendefinisikan pengertian & 1 & 11,76 & 59,56 & 47,80 \\
pereaksi pembatas & 2 & 11,76 & 69,12 & 57,36 \\
2. Menentukan pereaksi pembatas & 3 & 0 & 81,62 & 81,62 \\
& 4 & 0 & 67,06 & 67,06 \\
& 5 & 0 & 74,12 & 74,12 \\
& 6 & 0 & 63,24 & 63,24 \\
& 7 & 0 & 60,29 & 60,29 \\
\hline Rata-rata & & 3,36 & 65,82 & 64,50 \\
\hline
\end{tabular}

Pemahaman konsep yang kedua yaitu pemahaman menentukan pereaksi pembatas diperoleh persentase rata-rata pemahaman konsep tentang menentukan pereaksi pembatas sebesar 69,32\%.

Pemahaman konsep mendefinisikan pereaksi pembatas dalam tabel 8 merupakan indikator 1 dan pemahaman menentukan pereaksi pembatas adalah indikator 2. Persentase rata-rata indikator 1 dan indikator 2 adalah 64,50\%. Persentase pemahaman sebesar $64,50 \%$ tersebut bila dibandingkan dengan klasifikasi tingkat pemahaman digolongkan ke dalam kriteria baik, sehingga dapat diartikan bahwa pembelajaran dengan menggunakan LKS-Induktif dapat meningkatkan pemahaman siswa. Peningkatan pemahaman konsep siswa pada tabel 8 disajikan dalam grafik pada Gambar 3.

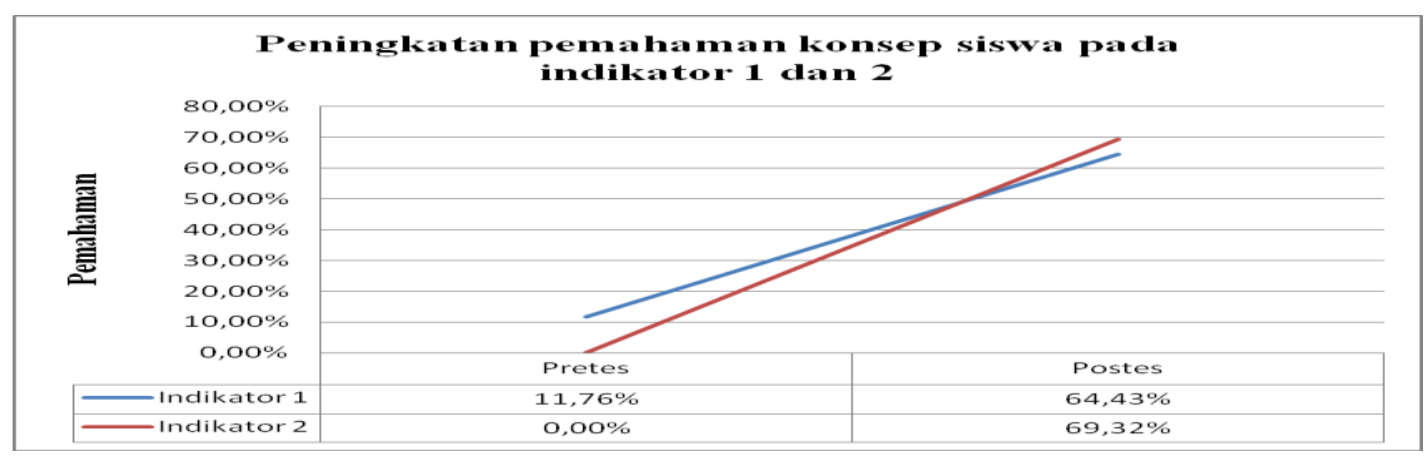

Gambar 2. Grafik peningkatan pemahaman konsep siswa pada 2 indikator dari data hasil pretes dan postes 
Gambar 2 menunjukkan pada setiap indikatornya ada peningkatan pemahaman siswa artinya setelah pembelajaran menggunakan LKS-Induktif terjadi peningkatan pemahaman siswa mengenai konsep pereaksi pembatas.

Sebelum belajar dengan LKS-Induktif, sebanyak 68 siswa memperoleh skor " 0 " pada pretes butir soal 6 artinya siswa tidak dapat mendeskripsikan dengan benar menentukan pereaksi pembatas jika diketahui data jumlah partikel masing-masing pereaksi. Setelah mengikuti serangkaian kegiatan pembelajaran dengan LKS-Induktif, siswa-siswa tersebut mengalami proses belajar dari tidak tahu pereaksi pembatas menjadi tahu, dari tidak paham definisi pereaksi pembatas menjadi memahami.

Sebelum belajar dengan LKS-Induktif, sebanyak 68 siswa memperoleh skor "0" pada pretes butir soal 6 artinya siswa tidak dapat mendeskripsikan dengan benar menentukan pereaksi pembatas jika diketahui data jumlah partikel masing-masing pereaksi, dimungkinkan siswa belum pernah menerima materi pereaksi pembatas Setelah mengikuti serangkaian kegiatan pembelajaran dengan menggunskan LKS-Induktif terdapat 6 orang yang masih memperoleh skor " 0 " pada postes.

Perubahan pemahaman konsep siswa juga didukung oleh aktivitas belajar secara kelompok. Hasil belajar (aktivitas belajar kelompok) berbantuan LKSInduktif yang baik, maka kecenderungan pemahaman konsep pun meningkat. Materi pereaksi pembatas berbantuan LKS-Induktif dipelajari dengan langkahlangkah berikut: Konsep sebagai prasyarat adalah perbandingan tetap (A) dan persamaaan reaksi $(\mathrm{B})$.

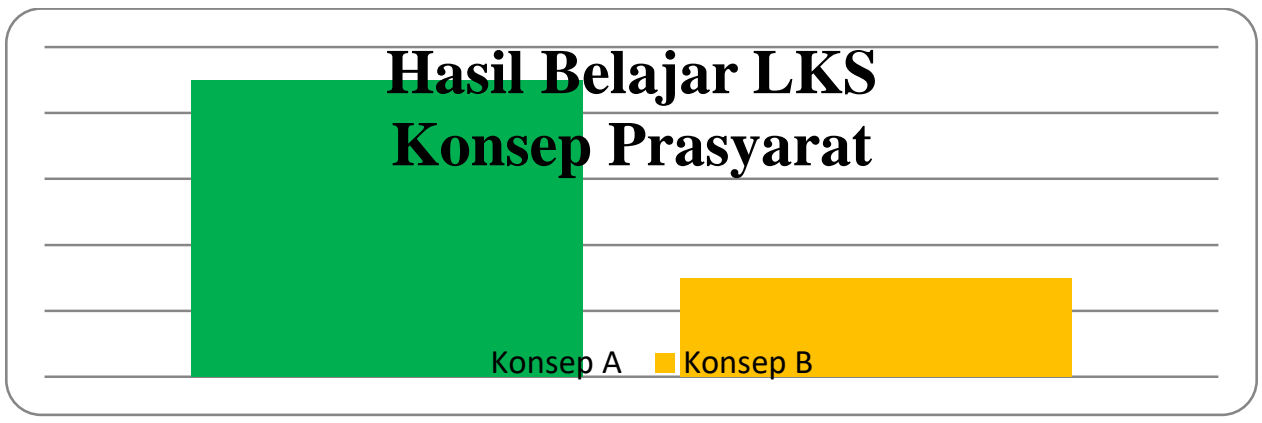

Gambar 3. Histogram Hasil Belajar LKS-Induktif Pada Konsep Prasyarat

Diperoleh rata-rata hasil belajar 68 siswa pada kegiatan mengingat konsep prasyarat sebesar 1,38 dan persentase hasil belajar sebesar $82,11 \%$, yaitu hasil belajar yang meliputi perbandingan mol pereaksi-pereaksi suatu persamaan reaksi sebesar $100 \%$, perbandingan koefisien pereaksi-pereaksi 81,37\%; mengamati adanya pereaksi yang habis bereaksi apabila perbandingan mol sesuai dengan perbandingan koefisiennya sebesar 93,38\%; dan hasil belajar mendefinisikan pereaksi pembatas sebesar $54 \%$. 


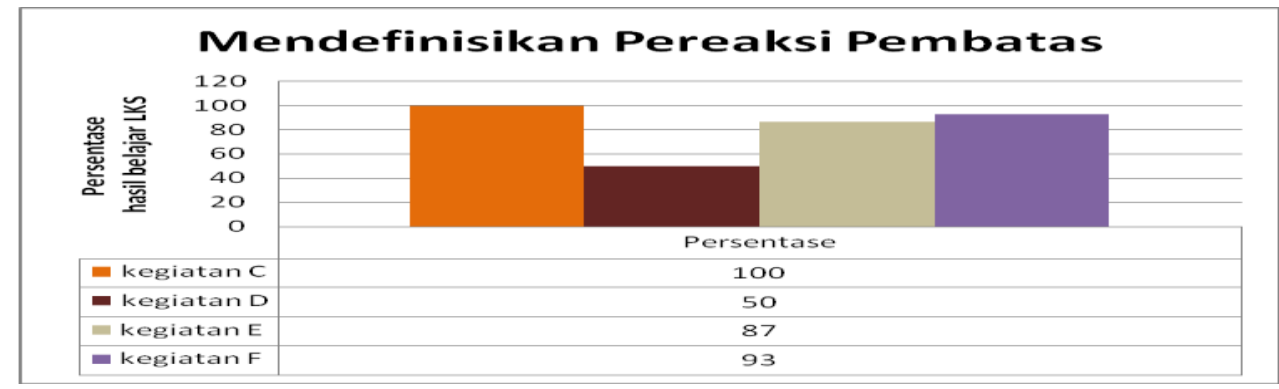

Gambar 4. Histogram Hasil Belajar LKS-Induktif Kegiatan Mendefinisikan Pereaksi Pembatas

Tabel 7. Persentase Menentukan Pereaksi Pembatas

\begin{tabular}{|c|c|}
\hline Kegiatan Mendefinisikan Pereaksi Pembatas & Persentase \\
\hline $\begin{array}{l}\text { menuliskan banyaknya mol atau massa atau } \\
\text { volume pada keadaan STP atau jumlah partikel } \\
\text { ataupun molaritas dari data yang disajikan pada } \\
\text { suatu reaksi }(\mathrm{G})\end{array}$ & 100 \\
\hline $\begin{array}{l}\text { mengkonversi mol dari massa atau volume } \\
\text { pada keadaan standar atau jumlah partikel } \\
\text { ataupun molaritas }(\mathrm{H})\end{array}$ & 100 \\
\hline $\begin{array}{l}\text { menghitung mol masing-masing pereaksi } \\
\text { dibagi dengan koefisiennya (I) }\end{array}$ & 33 \\
\hline $\begin{array}{l}\text { membandingkan nilai hasil bagi mol dengan } \\
\text { koefisien kedua pereaksi }(\mathrm{J})\end{array}$ & 20 \\
\hline $\begin{array}{l}\text { membuktikan ada pereaksi pembatas jika } \\
\text { pereaksi tersebut memiliki nilai hasil bagi mol } \\
\text { dengan koefisien lebih kecil dari hasil bagi mol } \\
\text { dengan koefisien pereaksi lain }(\mathrm{K})\end{array}$ & 33 \\
\hline $\begin{array}{l}\text { menyimpulkan pereaksi pembatas sebagai } \\
\text { pereaksi yang memiliki nilai hasil bagi mol } \\
\text { dengan koefisien lebih kecil dari hasil bagi mol } \\
\text { dengan koefisien pereaksi lain (L) }\end{array}$ & 50 \\
\hline Rata-rata (\%) & 56 \\
\hline
\end{tabular}

Terlihat pada tabel tersebut bahwa kegiatan menentukan pereaksi pembatas sebesar 56\%, sehingga kegiatan belajar menentukan pereaksi pembatas menggunakan LKS-Induktif dikategori sedang. Hasil belajar tersebut dapat dilihat dalam Gambar 5.

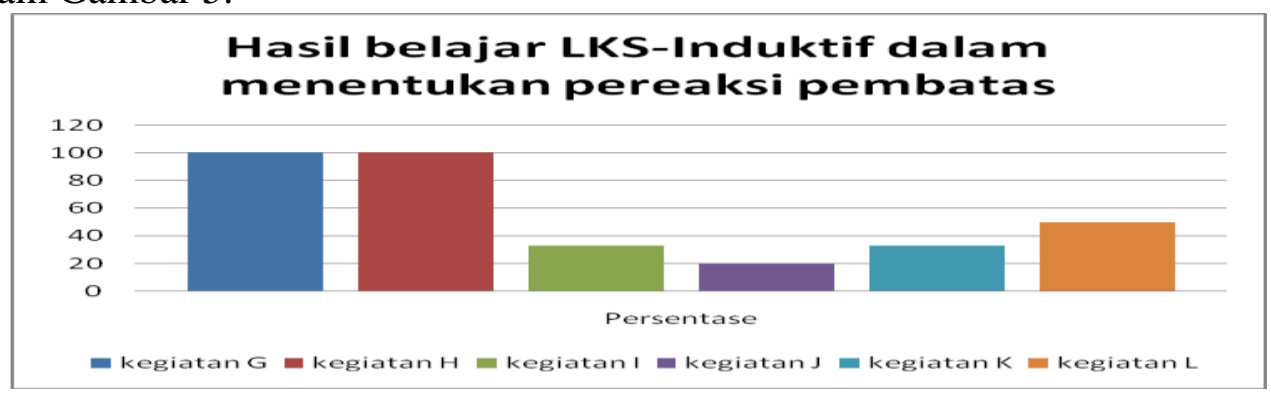

Gambar 5. Histogram Hasil Belajar LKS-Induktif Kegiatan Menentukan Pereaksi Pembatas 
Hasil belajar pereaksi pembatas berbantuan LKS-Induktif dengan langkah-langkah kegiatan yaitu 1) mengingat konsep prasyarat sebesar 88\%, 2) mendefinisikan pengertian pereaksi pembatas sebesar 58,25\%, dan 3) menentukan pereaksi pembatas sebesar 56\% terrangkum dalam Gambar 7.

Hasil belajar LKS-Induktif siswa yaitu mendefinisikan pereaksi pembatas sebesar $58,25 \%$, dan menentukan pereaksi pembatas sebesar $56 \%$ diklasifikasikan ke dalam tingkat pemahaman sedang. Keduanya lebih rendah dibandingkan dengan hasil belajar mengingat konsep prasyarat sebesar 88\%. Dimungkinkan, perubahan pemahaman konsep siswa sebelum dan sesudah pembelajaran mengenai pereaksi pembatas sebesar 64,50 \% tergolong pada kriteria sedang.

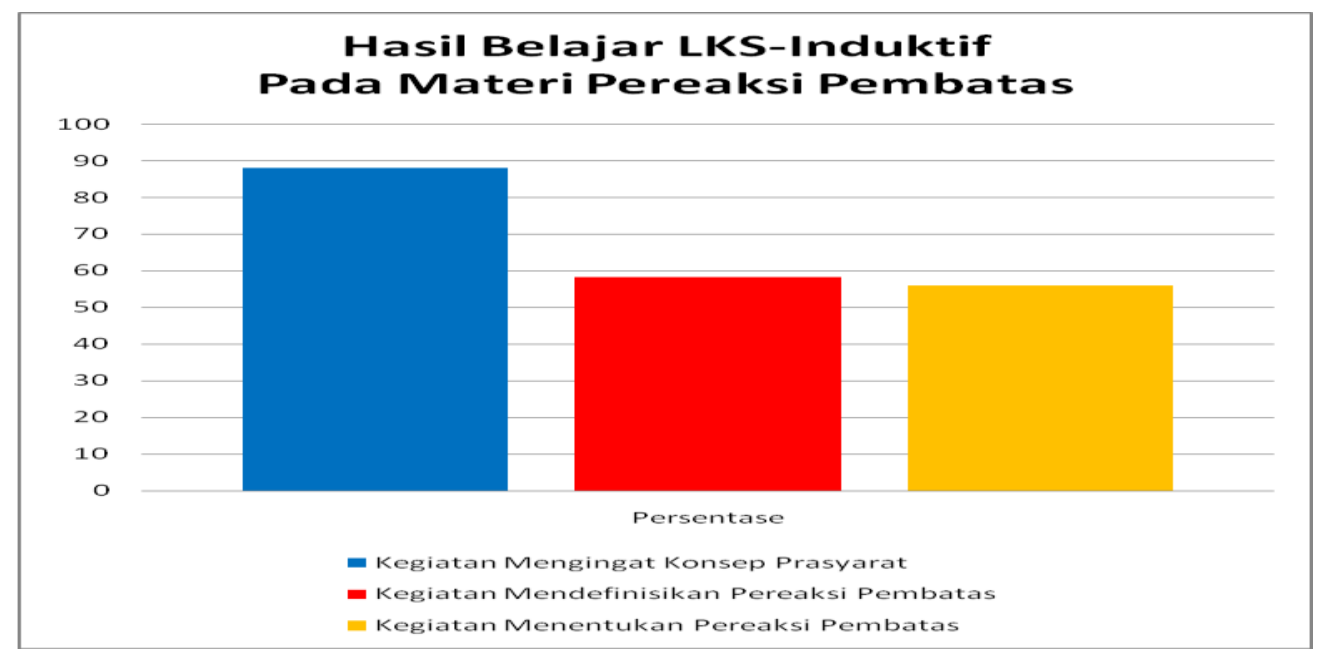

Gambar 6. Histogram Hasil Belajar LKS-Induktif

Pada Materi Pereaksi Pembatas

\section{Kesimpulan}

Hasil penelitian dapat disimpulkan bahwa: LKS-Induktif dapat meningkatkan pemahaman konsep pereaksi pembatas pada siswa kelas X SMA Negeri 1 Palangka Raya tahun pelajaran 2015/2016. Peningkatan pemahaman konsep sebesar $64,50 \%$ dari $3,36 \%$ sebelum pembelajaran dan setelah pembelajaran pemahaman meningkat menjadi 65,82\%. Penggunaan LKS-Induktif dikombinasikan dengan latihan soal terstruktur dalam pembelajaran kimia terutama mengenai konsep pereaksi pembatas. Penelitian yang akan datang mengenai konsep pereaksi pembatas dengan LKS-Induktif disarankan terlebih dahulu merevisi LKS-Induktif pada bagian mendefinisikan pengertian pereaksi pembatas, dan menentukan pereaksi pembatas agar diperoleh hasil belajar LKSInduktif mengenai pereaksi pembatas, yang dapat diklasifikasikan ke dalam kriteria baik.

\section{Daftar Rujukan}

Anderson, L.W. \& Krathwhol, D.R. (2010). Kerangka landasan pembelajaran, pengajaran dan asesmen. Judul asli: a taxonomy for learning, teaching and assessing: a revision of Bloom's taxonomy of educational objectives. Penerjemah: Agung Prihantoro. Pustaka Pelajar. 
Ningrum, E. S. (2011). Pengaruh Pemberian LKS Analogi Terhadap Pemahaman Konsep Pereaksi Pembatas pada Siswa Kelas XI IPA SMA Negeri 2

Palangka Raya. Skripsi. Tidak diterbitkan, Universitas Palangkaraya.

Rivai, Samsiar (2011). Pengetahuan Konseptual Dan Prosedural Dalam

Pembelajaran Perkalian Bilangan Pecah Desimal Berdasarkan Paham Konstruktivisme Pada Siswa SD Kelas V. Diambil pada tanggal 17 Juli 2016, dari ejurnal.fip.ung.ac.id/index.php/PDG/article/viewFile/265/259

Uno, Hamzah. (2007). Model Pembelajaran Menciptakan Proses Belajar yang Kreatif dan Efektif. Jakarta: PT Bumi Aksara. 